\title{
PENGARUH MODEL GENERATIVE LEARNING TERHADAP KEMAMPUAN PEMECAHAN MASALAH MATEMATIS DITINJAU DARI HABITS OF MIND SISWA SMA NEGERI DI KOTA TANGERANG
}

\section{THE EFFECT OF GENERATIVE LEARNING MODELS ON MATHEMATICAL PROBLEM SOLVING ABILITIES IN TERMS OF HABITS OF MIND STUDENT OF SENIOR HIGH SCHOOL IN TANGERANG CITY}

\author{
Nana Indi Saputria ${ }^{a}$, Suyono $^{b}$, Pinta Deniyanti Sampoerno ${ }^{c}$ \\ ${ }^{a}$ Program Studi Pendidikan Matematika Jenjang Magister FMIPA UNJ \\ Jl. Rawamangun Muka Raya. DKI Jakarta, nanaindisaputri@gmail.com \\ ${ }^{\mathrm{b}}$ Program Studi Pendidikan Matematika Jenjang Magister FMIPA UNJ \\ Jl. Rawamangun Muka Raya. DKI Jakarta, synjkt@yahoo.com \\ ${ }^{c}$ Program Studi Pendidikan Matematika Jenjang Magister FMIPA UNJ \\ Jl. Rawamangun Muka Raya. DKI Jakarta, pinta_ds@yahoo.com
}

\begin{abstract}
ABSTRAK
Penelitian ini bertujuan untuk mengetahui pengaruh model generative learning terhadap kemampuan pemecahan masalah matematis ditinjau dari habits of mind siswa SMA. Penelitian ini dilaksanakan di SMA pada kelas X semester genap tahun pelajaran 2018/2019. Penelitian ini menggunakan metode quasi eksperimental dengan desain penelitian treatment by level $2 \times 2$ yang terdiri dari dua variabel: (1) pendekatan pembelajaran dengan taraf model generative learning dan model konvensional, (2) habits of mind dengan taraf tinggi dan rendah. Sampel sebanyak 96 siswa SMA. Hasil penelitian ini menunjukan terdapat pengaruh penerapan model generative learning terhadap kemampuan pemecahan masalah matematis, khususnya untuk siswa yang memiliki habits of mind tinggi, dan terdapat interaksi antara model dan habits of mind terhadap kemampuan pemecahan masalah matematis.
\end{abstract}

Kata Kunci : kemampuan pemecahan masalah matematis, model generative learning, habits of mind.

\begin{abstract}
This study aims to determine the effect of generative learning models on mathematical problem solving ability in terms of the habits of mind of senior high school students. This research was conducted in senior high school in class X second semester of school year 2018/2019. This study used a quasi-experimental method with treatment by level $2 \times 2$ research design, consist of two variables: (1) learning approach with generative learning model and the conventional model, (2) high and low habits of mind. A sample of 96 senior high school students. The results of this study indicate that there is an effect of the implementation of generative learning model on mathematical problem solving ability, especially for students having high habits of mind, and there is an interaction between models and habits of mind on mathematical problem solving ability.
\end{abstract}

Kata Kunci : mathematical problem solving ability, generative learning models, habits of mind. 


\section{Pendahuluan}

Perkembangan di bidang pendidikan memiliki peranan penting dalam meningkatkan kesejahteraan kehidupan masyarakat. Pendidikan yang berkualitas merupakan penentu kemajuan suatu bangsa. Bangsa yang maju harus didukung oleh sumber daya manusia yang berkualitas. Indonesia sebagai negara yang berkembang, terus berupaya untuk meningkatkan kualitas sumber daya manusia melalui pendidikan nasional.

Pemecahan masalah merupakan kemampuan kognitif yang dianggap sebagai kecerdasan yang paling utama dalam aktivitas siswa. "Kemampuan pemecahan masalah tidak saja menuntut siswa untuk menyelesaikan masalah dengan cara biasa sesuai dengan rumus yang ada, tapi lebih pada kemampuan untuk penyederhanaan, modelling, menemukan konsep melalui pemodelan dan menggunakan konsep untuk menyelesaikan masalah yang lebih kompleks (NCTM 2000, Tohari, 2010, Hendriana et al 2018, Schraw et al 2012)". Tahap penyelesaian pemecahan masalah menurut Polya memuat empat tahap, yaitu understanding the problem, devising a plan, carrying out the plan, looking back.

Terdapat beberapa hasil penelitian kemampuan pemecahan masalah yang menunjukkan bahwa kemampuan pemecahan masalah matematis masih lemah. "Penelitian yang pertama dilakukan oleh Ubaidillah (2017) menunjukkan bahwa kemampuan pemecahan masalah matematis masih rendah secara keseluruhan memiliki nilai rata-rata sebesar 56,77". "Penelitian yang kedua dilakukan oleh Novitasari (2016) yaitu penelitian kualitatif deskriptif yang menunjukkan masih lemahnya kemampuan pemecahan masalah matematis siswa". "Hasil dari penelitian Sodikin (2015) menjelaskan bahwa siswa masih memiliki hambatan dalam membangun kemampuan pemecahan masalah matematis, karena dalam pembelajaran matematika selama ini siswa tidak pernah atau jarang diberikan kesempatan untuk menghadirkan kemampuan pemecahan masalahnya sendiri".

Mengembangkan kemampuan pemecahan masalah siswa harus dengan penerapan model pembelajaran yang tepat. Kemampuan pemecahan masalah dapat dicapai secara optimal dengan menggunakan model generative learning. Tahap-tahap model generative learning memliki keterkaitan dengan indikator pemecahan masalah menurut polya. "Model generative learning terdiri dari lima tahap, yaitu Tahap Pendahuluan/Eksplorasi, $\quad$ Tahap Pemfokusan, Tahap Tantangan, Tahap Penerapan Konsep, Melihat Kembali atau Mereview (Osborne dan Wittrock 1985, Hakim 2014, Hyeon 2008, Moma 2013)".

Kegiatan pembelajaran generative learning tidak dapat dipisahkan dari Habits of mind yang ada pada diri siswa. Sebab Habits of mind akan memberikan kontribusi terhadap kualitas pengetahuan yang akan didapat siswa sehingga menjadi bermakna. "Diidentifikasi bahwa terdapat 16 gambaran habits of mind, yaitu: (1) bertahan atau pantang menyerah, (2) berpikir dan berkomunikasi dengan jelas dan tepat, (3) mengelola impulsif, (4) memanfaatkan indera dalam mengumpulkan dan 
mengelola data, (5) mendengarkan dengan pengertian dan empati, (6) berkarya, berimajinasi dan berinovasi, (7) berpikir fleksibel (luwes), menanggapi dengan keheranan dan kekaguman, (9) berpikir tentang berpikir (metakognisi), (10) bertanggung jawab atas resiko, (11) berusaha bekerja teliti dan tepat, (12) humoris, (13) bertanya dan mengajukan masalah, (14) berpikir interdependently (saling bergantung), (15) menerapkan pengetahuan masa lalu dalam situasi baru, (16) tetap terbuka untuk belajar (Costa dan Kallick 2008, Cuoco et al 2010, Korkmaz et al 2016)".

Tingkatan habits of mind dengan kategori tinggi dan rendah diharapkan memudahkan guru dalam memantau kemajuan belajar siswa saat mengembangkan kemampuan pemecahan masalah matematis siswa secara optimal. Model generative learning yang didukung habits of mind dalam pembelajaran matematika akan memberikan peluang kepada siswa agar dapat menentukan ide atau gagasangagasan yang kemudian siswa dapat dengan mudah merepresentasikan pemikiran mereka dalam menyelesaikan permasalahan yang ditemukan serta memberikan alasan pada setiap langkah yang diambil, dengan cara melihat kembali apa yang dikerjakan.

Tujuan penelitian ini adalah untuk mengetahui

1. Pengaruh Model generative learning terhadap kemampuan pemecahan masalah matematis siswa.

2. Pengaruh interaksi antara model pembelajaran dan habits of mind terhadap kemampuan pemecahan masalah matematis siswa.
3. Pengaruh model generative learning terhadap kemampuan pemecahan masalah matematis siswa dengan habits of mind tinggi dan habits of mind rendah.

\section{Metode Penelitian}

Penelitian menggunakan desain quasi experimental yang melibatkan dua faktor, yaitu model pembelajaran dan habits of mind. Habits of mind dibagi menjadi dua, yaitu habits of mind tinggi (B1) dan habits of mind rendah (B2). Model pembelajaran pun terdiri menjadi dua, yaitu model generative learning (A1) dan model konvensional (A2).

Populasi target dalam penelitian ini adalah seluruh siswa di SMAN 3 Kota Tangerang dan SMAN 13 Kota Tangerang pada semester Genap tahun ajaran 2018/2019. Populasi terjangkau dalam penelitian ini adalah seluruh siswa kelas X MIPA. Teknik pengambilan sampel menggunakan simple random sample. Data nilai UTS semester genap dari populasi terjangkau dilakukan uji normalitas, uji homogenitas dan uji kesamaan rata-rata terlebih dahulu. Kemudian kedua kelompok siswa diberi angket habits of mind. Dari hasil pengambilan sampel, kemudian siswa dikelompokan menjadi dua kategori yaitu siswa yang memiliki habits of mind tinggi dan siswa yang memiliki habits of mind rendah.

Penerapan model generative learning diawali dengan tahap eksplorasi, yaitu guru membimbing siswa untuk melakukan eksplorasi terhadap pengetahuan, ide atau konsepsi awal yang diperoleh dari pengalaman sehari-hari atau diperoleh dari pembelajaran pada tingkatan kelas sebelumnya. Selanjutnya 
tahap pemfokusan, pada tahap ini siswa diberi kesempatan untuk mengemukakan ide mereka mengenai topik tertentu. Penyelesaian tugas dilakukan secara berkelompok terdiri 4 sampai 5 siswa. Setelah itu tahap tantangan atau disebut juga tahap pengenalan konsep. Setelah siswa memperoleh data, selanjutnya menyimpulkan dan menulis pada Lembar Kerja Siswa (LKS). Siswa mempresentasikan temuannya melalui diskusi kelas. Pada tahap keempat yaitu penerapan konsep, siswa diajak untuk memecahkan masalah dengan menggunakan pengetahuan barunya dalam situasi baru yang berkaitan dengan hal-hal praktis dalam kehidupan seharihari. Tahap terakhir yaitu melihat kembali atau meriview. Pada tahap ini siswa diberi kesempatan untuk mengevaluasi kelemahan dari pemahaman konsep yang dikonstruksinya dan mampu memberikan alasan yang tepat tentang pengetahuan baru yang mereka temukan, serta dapat mengingat kembali materi yang telah mereka pelajari.

Pada model konvensional, pada awal pembelajaran guru menjelaskan materi pembelajaran di depan kelas dan memberikan contoh soal yang dikerjakan bersama-sama oleh guru dan murid. Setelah itu, guru memberikan latihan soal yang dikerjakan secara individu oleh siswa. Guru meminta siswa untuk menuliskan jawaban di depan kelas dan dibahas bersama-sama murid yang lain dan juga guru. Setelah itu, guru dan siswa menyimpulkan materi yang telah dipelajari.

Instrumen kemampuan pemecahan masalah matematis berupa tes esai dan instrumen habits of mind berupa angket dengan lima opsi. Indikator kemampuan pemecahan masalah matematis terdiri dari memahami masalah, merencanakan penyelesaian, melaksanakan rencana, dan melihat kembali hasil. Indikator habits of mind terdiri dari 16 gambaran yang dikemukan oleh Costa dan Kallick (2008). Kedua instrumen dilakukan validitas isi oleh ahli untuk melihat kesesuaian dengan indikator, materi, konstruksi dan bahasa. Penentuan kelompok siswa dengan habits of mind tinggi dan rendah menggunakan kategori (Moma, 2018) seperti pada Tabel 1:

Tabel 1. Kategori Habits Of Mind

\begin{tabular}{cc}
\hline Kategori & Rumus \\
\hline Tinggi & $M i+1,0 S D i \leq X$ \\
\hline Sedang & $M i-1,0 S D i \leq X<M i+1,0 S D i$ \\
\hline Rendah & $X<M i-1,0 S D i$ \\
\hline
\end{tabular}

\section{Hasil dan Pembahasan}

\section{Hasil}

Skor hasil post-test kemampuan pemecahan masalah matematis siswa yang diberikan perlakuan menggunakan model generative learning dengan siswa yang menggunakan model konvensional pada siswa dengan habits of mind tinggi dan rendah dapat dilihat pada Tabel 2:

Tabel 2. Statistik Deskriptif Kemampuan Pemecahan Masalah Matematis

\begin{tabular}{cccc}
\hline Data & $\bar{x}$ & Mo & SD \\
\hline $\mathrm{A}_{1}$ & 18,81 & 20 & 5,445 \\
\hline $\mathrm{A}_{2}$ & 15,98 & 14 & 4,082 \\
\hline $\mathrm{A}_{1} \mathrm{~B}_{1}$ & 21,92 & 20 & 5,241 \\
\hline $\mathrm{A}_{2} \mathrm{~B}_{1}$ & 17,13 & 18 & 4,276 \\
\hline $\mathrm{A}_{1} \mathrm{~B}_{2}$ & 15,71 & 18 & 3,605 \\
\hline $\mathrm{A}_{2} \mathrm{~B}_{2}$ & 14,83 & 12 & 3,608 \\
\hline
\end{tabular}


Pada Tabel 2, menunjukan bahwa sebaran data pada kelompok siswa $\mathrm{A}_{1}$ dan kelompok siswa $A_{2}$ berbeda cukup jauh dan terlihat pula pada rata-rata skor kedua kelompok tersebut yang memiliki selisih yang cukup banyak. Kelompok siswa $A_{1} B_{1}$ dan kelompok siswa $A_{2} B_{1}$ memiliki sebaran data yang hampir sama tingkat homogennya, namun bila dilihat pada rata-rata skor kedua kelompok tersebut memiliki selisih yang sangat banyak. Sedangkan untuk kelompok siswa $\mathrm{A}_{1} \mathrm{~B}_{2}$ dan kelompok siswa $\mathrm{A}_{2} \mathrm{~B}_{2}$ memiliki sebaran data yang hampir sama tingkat homogennya dan apabila dilihat rata-rata skor kedua kelompok tersebut memiliki selisih yang sangat sedikit.

Tabel 3. Pengujian Kemampuan

Pemecahan Masalah Matematis

\begin{tabular}{cccc}
\hline Kelompok & $\begin{array}{c}\text { Anava } \\
\text { Dua } \\
\text { Jalur } \\
\text { (Sig.) }\end{array}$ & $\begin{array}{c}\text { Uji- } t \\
\text { (Sig.) }\end{array}$ & $\begin{array}{c}\text { Effect } \\
\text { Size }\end{array}$ \\
\hline $\mathrm{A}_{1}><\mathrm{A}_{2}$ & 0,001 & 2,885 & 0,693 \\
\hline$A \times B$ & 0,026 & - & - \\
\hline $\mathrm{A}_{1} \mathrm{~B}_{1}><\mathrm{A}_{2} \mathrm{~B}_{1}$ & - & 3,470 & 1,120 \\
\hline $\mathrm{A}_{1} \mathrm{~B}_{2}><\mathrm{A}_{2} \mathrm{~B}_{2}$ & - & 0,840 & 0,143 \\
\hline
\end{tabular}

Pada Tabel 3, menunjukan bahwa model generative learning memiliki pengaruh terhadap kemampuan pemecahan masalah matematis, serta memiliki kemampuan pemecahan masalah matematis yang lebih tinggi dari siswa yang menggunakan model konvensional. Terdapat interaksi antara model pembelajaran dengan habits of mind terhadap kemampuan pemecahan masalah matematis. Interaksi dalam hal ini berarti bahwa model pembelajaran yang digunakan dengan tingkat habits of mind yang dimiliki siswa dapat memberikan pengaruh yang terhadap peningkatan kemampuan pemecahan masalah matematis siswa. Kemampuan pemecahan masalah matematis siswa yang diberi perlakuan menggunakan model generative learning lebih tinggi dari siswa yang menggunakan model konvensional pada kelompok siswa yang memiliki habits of mind tinggi. Tidak terdapat perbedaan kemampuan pemecahan masalah matematis antara siswa yang diberi perlakuan menggunakan model generative learning dengan siswa yang menggunakan model konvensional pada kelompok siswa yang memiliki habits of mind rendah.

\section{Pembahasan}

Model generative learning memiliki pengaruh yang cukup besar terhadap kemampuan pemecahan masalah matematis yaitu sebesar 0,693. Hal ini karena model generative learning menekankan pada tahap eksplorasi yang berasal dari pengalaman hidup sehari-hari siswa yang kemudian dikaitkan dengan materi pembelajaran untuk mendapatkan konsep atau informasi baru, sehingga dapat memotivasi siswa membuat hubungan antara pengetahuan dengan penerapannya dalam kehidupan mereka. Model generative learning secara efektif membantu siswa untuk menghubungkan pengetahuan dan konteks yang terkait dalam kehidupan sehari-hari. Tahap Eksplorasi, siswa belajar secara aktif dengan melakukan langsung, melalui eksplorasi, penemuan, dan rekaan terhadap hal yang dikaji dan berusaha sendiri menemukan hal atau konsep baru dari apa yang dipelajari agar siswa lebih mudah dalam memahami konsep tersebut. "Hal ini sejalan dengan penelitian penelitian dari Alba (2013) 
juga menyatakan bahwa kemampuan pemecahan masalah matematik dengan model generative learning lebih baik dari pada siswa yang pembelajarannya secara konvensional".

Berdasarkan analisis data menunjukan adanya interaksi antara pembelajaran dan habits of mind berpengaruh terhadap kemampuan pemecahan masalah matematis. Interaksi yang dimaksud dalam penelitian ini adalah dalam hal menggunakan model generative learning dan model konvensional terhadap kemampuan pemecahan masalah matematis bergantung pada habits of mind.

Siswa yang memiliki habits of mind tinggi yang diberikan model generative learning mampu mengembangkan dan mendorong kemampuan pemecahan masalah matematis. Siswa dengan habits of mind tinggi kebiasaan berpikir yang kuat dalam menyelesaikan berbagai macam soal matematika baik mulai dari soal-soal yang mudah sampai dengan yang sulit. Model generative learning memiliki tahap pemfokusan dan tantangan yang merupakan pembelajaran dalam konteks interaksi kelompok yang saling berbagi, merespon, berkomunikasi dalam menguasai materi pembelajaran untuk mengembangkan potensi serta pengetahuan yang dimiliki, sehingga apa yang dipelajari dapat lebih bermakna. Siswa yang memiliki habits of mind tinggi akan merasa nyaman selama proses pembelajaran aktif dalam kelompok tersebut sehingga mereka mendapatkan manfaat yang banyak dari model generative learning tersebut dan terbukti dengan perhitungan effect size yang sangat tinggi yaitu sebesar 1,120. Sejalan dengan penelitian dari Masni (2017) bahwa siswa yang memiliki habits of mind tinggi maka kemampuan pemecahan masalahnya juga tinggi dan siswa yang memiliki habits of mind rendah maka kemampuan pemecahan masalahnya juga rendah.

Sedangkan, siswa dengan habits of mind rendah memiliki kebiasaan berpikir yang lemah sehingga tidak nyaman ketika diberi perlakuan menggunakan model generative learning dan cenderung bersifat pasif, sehingga kemampuan pemecahan masalah matematis siswa yang diberi perlakuan menggunakan model generative learning dan siswa yang menggunakan model konvensional memiliki hasil yang hampir sama. Hal ini dikarenakan pada siswa dengan habits of mind rendah cenderung sulit untuk merubah pandangan terhadap kemampuan dirinya, terbukti dengan perhitungan effect size yang sedikit yaitu sebesar 0,143. Hal ini sejalan dengan pendapat Mawaddah (2015) bahwa siswa yang pasif cenderung lebih nyaman dengan pembelajaran konvensional, karena tidak perlu berprilaku aktif dalam pembelajaran.

\section{Kesimpulan}

Model generative learning cocok diterapkan dalam meningkatkan kemampuan pemecahan masalah matematis karena terbukti memberikan pengaruh yang cukup besar. Secara khusus, model generative learning sangat cocok diterapkan untuk siswa yang memiliki habits of mind tinggi. Hal ini dikarenakan, siswa yang memiliki habits of mind tinggi akan merasa tertantang dan semakin berusaha keras untuk menyelesaikan persoalan yang sulit. Dari penelitian ini, diharapkan guru dalam 
memberikan layanan pendidikan kepada siswa, tidak hanya memperhatikan aspek kognitif seperti hasil belajar, tetapi juga memperhatikan aspek afektif berupa habits of mind siswa. Guru juga diharapkan dapat menerapkan pembelajaran dengan model generative learning dalam proses pembelajaran, serta habits of mind siswa yang nantinya akan berdampak pada peningkatan hasil belajar siswa.

\section{Pustaka}

Alba, F. M. 2013, Keefektifan Model Pembelajaran Generatif dan MMP terhadap kemampuan pemecahan Masalah, Jurnal Kreano, 4(2).

Costa, A. L. dan Kallick, B. 2008. Learning and Leading With Habits of Mind, Alexandria: Association for Supervision and Curriculum Development.

Cuoco, A., Goldenberg, E. P., and Mark, J. 2010, Contemporary curriculum issues: Organizing a curriculum around mathematical habits of mind, Mathematics Teacher, 103(9): 682-688.

Hakim, A. R. 2014, Pengaruh Model Pembelajaran Generatif Terhadap Kemampuan Pemecahan Masalah Matematika, Jurnal Formatif, 4(3): 196-207.

Hendriana. H, et al, 2018, The Role of Problem-Based Learning to Improve Students' Mathematical Problem-Solving Ability and Self Confidence, Journal On Mathematics Education, 9(2)

Hyeon. W 2008, "The Effects of Generative Learning Strategy Prompts and Metacognitive Feedback on Learners' Self Regulation, Generation Process, and Achievement", Dissertation Instructional Systems.

Korkmaz, S., Dundar, S., Yaman,H. 2016, The Mathematical Habits of Mind in Problem Solving, Turkish journal of computer, 7(1): 35-61.

Masni, E. D. 2017, Asosiasi Kemampuan Pemecahan Masalah Dan Mathematical Habits Of Mind Siswa SMP. Jurnal Penelitian Pendidikan INSANI, 20(1): 38-44.

Mawaddah, S. 2015, Kemampuan Pemecahan Masalah Matematis Siswa Pada Pembelajaran Matematika dengan Menggunakan Model Pembelajaran Generatif (Generative Learning) di SMP, Jurnal Edu-Mat, 3(2).

Moma, L. 2014, Peningkatan Self Efficacy Matematis Siswa SMP Melalui Pembelajaran Generatif, Jurnal Cakrawala pendidkan.

Moma, L. 2018, "Pengembangan Habits Of Mind Matematis Mahasiswa Dalam Perkuliahan Geometri Analitik Ruang", Prosiding SEMNAS Matematika \& Pendidikan Matematika (IAIN Ambon), hal 142-150.

NCTM. 2000, Principles and Standards for School Mathematics. Reston: The National Council of Teachers of Mathematics, Inc.

Novitasari, 2018, Analisis Kemampuan Pemecahan Masalah Matematika Siswa, Jurnal Prima, 4(2).

Osborne dan Wittrock. 1985, "The Generative Learning Model and Its Implications for Science Education", in Journal Studies in Science Education v12.

Schraw, G. Bendixen, L. D dan Dunkle. M. E. 2002, "Development and Validation of The Epistemic Belief Inventory (EBI)." Personal Epistemology: Thepsychology of Beliefs About Knowledge and Knowing. NJ: Lawrence Erlbaum Associates, Inc. 
Sodikin, A. 2015, Peningkatan kemampuan pemecahan masalah siswa melalui strategi abduktifdeduktif pada pembelajaran matematika. Jurnal Matematika Kreatif-Inovatif, 6(2), hlm 101110.

Tohari. K. 2010. Peningkatan Kemampuan Problem Solving Melalui Peningkatan Kemampuan Metakognisi. Surabaya: Artikel KEMENAG. 